Por sua vez, os meninos são um desafio constante. Nada do que era possivel fazer em outras situações, com outros meninos, em outras escolas, era possível fazer na Casa. Tudo precisava ser reformulado constantemente: a forma de aproximação, as estratégias de trabalho, as técnicas de alfabetização, as práticas pedagógicas. Parece que nada do que era conhecido antes podia ser pensado $\mathrm{co}^{-}$ mo referência.

Nāo obstante, nesse aparente caos, algumas coisas se delineavam e se marcavam com uma significaçāo especial na Casa. A Assembléia, por exemplo, tornava-se um momento comunitário de trabalho de todos, de discussão e de reflexão acerca do diaa-dia, enfim, um espaço privilegiado em que se pensavam as questões que inquietavam a mini comunidade. Julgávamos que a Casa tinha nela uma forma peculiar de tornar coletivos os conteúdos, as vivências pessoais. A Assembléia nos mostrava que ela acontecia de uma forma nova, inesperada para nós, mas configurada como um espaço singular de convivência.

Permanecem grandes interrogações: trata-se de caminhar por algumas estradas já abandonadas, outras jamais percorridas, para chegar a um ponto que ainda desconhecemos."

\section{o 00}

Todos os relatos foram extraidos do livro Um tiro de amor para todos vocês.

Aos interessados, maiores informações podem ser obtidas pelo telefone (031) 463-0888, ramal 192, em Belo Horizonte, $M G$.

\title{
Autogoverno: uma alternativa
}

Quando jovens e adultos, vivendo em instituiçōes sociais corretivas ou educacionais, nảo têm oportunidade de participar na elaboração das normas que regerão suas próprias relações, observa-se freqüentemente, como conseqüência, o desenvolvimento de todo um código informal de normas, paralelamente ao "código oficial" imposto. Esse código informal é que efetivamente controlará as relaçōes da população institucionalizada, visto que foi elaborado com a participação efetiva de seus membros, sendo fruto, portanto, de suas necessidades reais. Vide o exemplo do que ocorre nas penitenciárias e antigos reformatórios.

$A$ análise da literatura demonstra várias experiências educacionais, a maioria com jovens considerados "pré-delinqüentes ou delinqüentes", planejadas e desenvolvidas de acordo com o princípio acima exposto, as quais podem ser agrupadas sob o título de autogoverno. Neill planejou Summerbill com essas características; Empey relata resultados animadores no trabalho com "delinqüentes"; Phillips e Phillips desenvolveram em Kansas City (USA) procedimentos de autogoverno nos lares, conhecidos como Achievement Place.

Mas, sem dúvida, foi Makarenko, o grande educador russo, que melhor desenvolveu e refletiu sobre os fundamentos do auto-governo, a partir do seu trabalho com delinqüentes, na Colônia Gorky, no período pós-revolução; os seus Poemas Pedagógicos são leitura obriga- tória para os atuais educadores que atuam com menores $e$ adolescentes institucionalizados.

Em linhas gerais, o autogoverno é um procedimento institucional em que os jovens devem discutir e estabelecer todas as normas que regerão seus comportamentos e suas relaçōes dentro e fora da instituição. Todas as experiências têm em comum a existência de uma instância (assembleia, conselho, reuniāo geral etc.) decisória, que se reúne sistematicamente, onde todos decidem sobre tudo. Contam com a participação de educadores muito bem preparados, que participam fundamentalmente como instigadores $e$ animadores do grupo. No entanto, sua opiniảo vale apenas um voto.

Esses autores relatam entusiasticamente os resultados: a situação de auto governo tem-se mostradocomo uma grande alternativa no sentido de representar um processo eficiente que garante a aprendizagem dos princípios sociais básicos para as relações humanas, como a questão dos direitos e deveres, o respeito às necessidades coletivas e aos direitos individuais, desenvolvimento da noção de justiça e a própria questāo da necessidade da organizaçāo grupal para o enfrentamento dos problemas comuns. Neste sentido, é fundamental a questão do tempo para o desenvolvimento do processo.

Pode-se perceber, no entanto, que uma das condiçōes fundamentais para o sucesso da proposta é que os educadores estejam plenamente con-

\section{educacional}

victos dos seus pressupostos filosóficos subjacentes, os quais implicam nào só a proposta educacional, mas principalmente uma determinada concepção de Homem e de Mundo coerente com a mesma. No autogoverno, a questão central é a idéia de que a solução para os problemas humanos nào está a nível individual, mas sim a nivel do coletivo, e neste sentido é uma proposta educacional concreta, que nảo fica só no discurso.

Outra condiçāo fundamental é que o autogoverno implica uma outra maneira de se pensar a instituição, pois coloca efetivamente o educando como centro do processo e, de novo, concretiza a idéia indo muito além do nível do discurso.

Em suma, o autogoverno representa uma condição educacional muito rica não só para os jovens e adolescentes, mas também para os educadores que a desenvolvem.

REFERÊNCIAS BIBLIOGRÁFICAS

MAKARENKO, A. S. The roed to life. Moscow, Foreing Language Publishing House, 1953.

MAKarenko, A. S. Poemo Pedagógico $V$ 1/2. Săo Paulo, Brasiliense, 1985

EMPEY L. T. The provo experiment: a brief review, Califórnia, Youth Studies Center, University of Southern, 1966.

PHILlIPS, E. L. Achievement Place: token reinforcement procedures in a homestyle rehabilitation setting for "pre-delinquent" boys. Journal of Applied Behavior Analysis 1968, I, 213.223

NEILL. A. S. Summerbill. New York, Hart Publishing, 1960 